\title{
Prevalence and Concentration of Escherichia coli 0157:H7 in Cattle, Products, and the Environment in the United States of America: A Meta-Analysis Study
}

\author{
Yilkal Woube ${ }^{1, *}$, Ehsan Abdella ${ }^{2}$, Rawah Faraj ${ }^{3,4}$, Ruby Perry ${ }^{2}$, Gopal Reddy ${ }^{2}$, Gemechu Wirtu ${ }^{3}$ and Woubit Abebe ${ }^{1,2}$ \\ ${ }^{1}$ Center of Excellence for Food Animal Health, Food Safety, and Food Defense, College of Veterinary Medicine, Tuskegee University, USA \\ ${ }^{2}$ Department of Pathobiology, College of Veterinary Medicine, Tuskegee University, USA \\ ${ }^{3}$ Department of Biomedical Science, College of Veterinary Medicine, Tuskegee University, USA \\ ${ }^{4}$ Department of Community Health, Institute of Medical Technology, Middle Technical University, Baghdad, Iraq
}

*Corresponding author: Yilkal Woube, Center of Excellence for Food Animal Health, Food Safety, and Food Defense, College of Veterinary Medicine, Tuskegee University, USA, E-mail: ywoube0923@tuskegee.edu

Received: 10 Aug, 2021 | Accepted: 11 Sep 2021 | Published: 17 Sep, 2021

Citation: Woube Y, Abdella E, Faraj R, Perry R, Reddy G, et al. (2021) Prevalence and Concentration of Escherichia coli O157:H7 in Cattle, Products, and the Environment in the United States of America: A Meta-Analysis Study. J Epidemiol Public Health Rev 6(3): dx.doi. org/10.16966/2471-8211.216

Copyright: (C) 2021 Woube $\mathrm{Y}$, et al. This is an open-access article distributed under the terms of the Creative Commons Attribution License, which permits unrestricted use, distribution, and reproduction in any medium, provided the original author and source are credited.

\begin{abstract}
Shiga toxin-producing Escherichia coli $\mathrm{O} 157: \mathrm{H7}$ are bacterial pathogens that cause foodborne infections in humans. The objectives of this study were to find the pooled prevalence and concentration of Escherichia coli 0157:H7 in cattle, hides, carcass, and the environment in the United States of America using meta-analysis. The PRISMA and MOOSE research protocols were employed in the methodology. Weighted effect size was calculated using MetaXL software. A total of 1737 publications were screened, out of which 53 were selected for the final analysis. The pooled prevalence in feedlot cattle was $10.96 \%$ (95\% Cl: $4.2-18.8 \%)$. In dairy cattle a pooled prevalence of $1.5 \%$ (95\% Cl: $0.11-3.5 \%)$ was observed. The prevalence between feedlot and dairy cattle was significantly different $(p<0.05)$. The herd prevalence in combined feedlot and dairy cattle was $31.7 \%(95 \%$ $\mathrm{Cl}$ : 10.2-55.5\%). Hide and carcass samples' pooled prevalences were $54.7 \%$ (95\% Cl: $41.7-67.5 \%)$ and $21.3 \%$ (95\% Cl: $9.7-34.2 \%)$, respectively. Prevalence of environmental samples was $8.1 \%$ for produce $(95 \% \mathrm{Cl}$ : $0-29.6 \%), 4.6 \%$ for watershed and sediment samples $(95 \% \mathrm{Cl}$ : 0-12.2\%), and $2.4 \%$ for water taken from troughs ( $95 \% \mathrm{Cl}: 0.39-5.1 \%)$. Significant difference was observed in individual, herd, and environment prevalence between regions $\left(\chi^{2}=903.14, p=0.0000 ; \chi^{2}=11.06, p=0.0039 ; \chi^{2}=13.59, p=0.0004\right.$, respectively). E. coli 0157: $\mathrm{H} 7$ concentrations were highest in feces (900$300,000 \mathrm{cfu} / \mathrm{g})$, followed by hides $(5-9,800 \mathrm{cfu} / 100$ square $\mathrm{cm})$, and carcass (1-189 cfu/100 square cm). At least one supershedder exists in a herd. The findings in this study showed that Escherichia coli 0157:H7 serotype is widespread in feedlots, herds, hides, and carcass in the United States of America necessitating appropriate measures to prevent human illnesses. Improving management programs in cattle herds, reduction of environmental contamination, and hygienic slaughter practices are targets of intervention.
\end{abstract}

Keywords: Escherichia coli 0157: H7; Prevalence; Concentration; Cattle; Feces; Hide; Carcass; Environment; Meta-analysis; United States of America

\section{Introduction}

Shiga Toxin-producing Escherichia coli (STEC) are bacterial foodborne pathogens producing disease in humans characterized by diarrhea, Hemorrhagic Colitis (HC), and Hemolytic Uremic Syndrome (HUS) [1-3]. From about 500 O-serotypes of Shiga toxinproducing Escherichia coli isolated so far from humans with disease, only seven serogroups (O26, O45, O103, O111, O121, O145, and O157:H7) are associated with severe clinical illness [2]. One of these serotypes, Escherichia Coli O157:H7 (E. coli O157:H7), is studied extensively.

E. coli $\mathrm{O} 157: \mathrm{H7}$, responsible for the majority of human enterohemorrhagic diseases, has a worldwide distribution [4]. Outbreaks of illnesses associated with E. coli O157:H7 have been reported throughout the northern hemisphere, most frequently
Canada, Japan, the United Kingdom, and the United States of America [5]. The pathogens most often implicated in outbreaks caused by consumption of fruits and vegetables from 2009 to 2010 were norovirus, Salmonnella species and E. coli O157:H7 [6]. The predominant serotype isolated from patients among Enterohemorrhagic E. coli (EHEC) group was E. coli O157:H7 [1]. E. coli $\mathrm{O} 157: \mathrm{H} 7$ infection alone is responsible for 73,480 illnesses, 2,168 hospitalizations, and 61 deaths annually in the United States [7]. Besides causing foodborne illnesses, E. coli O157:H7 is associated with economic losses. Since the 1980 s, more than $\$ 2$ billion have been spent by the cattle industry to combat $E$. coli O157:H7 and STEC in processing plants [8].

Cattle are natural reservoirs of STEC serotypes including E. coli O157:H7 $[9,10]$. However, except less than three days old neonatal calves [11], cattle do not suffer disease as they lack vascular receptors 
in their tissues [12]. E. coli O157:H7 colonizes the terminal colon specifically the Rectoanal Junction (RAJ) mucosa [13-16]. In colonized cattle, a unique class of cattle known as "supershedders" are responsible for most of the contamination of the population $[17,18]$. Supershedders are defined as animals with E. coli O157:H7 concentrations of at least $10^{3}$ Colony Forming Units (cfu) per gram of feces $[3,15,19]$. Feces are the major source of contamination to beef and produce [20]. In Scotland clustering of human infections was associated with regions with high cattle to people ratio [2123]. A direct link between cattle and human infection has been established by phage typing and Pulsed Field Gel Electrophoresis (PFGE) [24,25].

Important sources of STEC O157 contamination in the United States of America are food [7,26,27], water [28,29], pen floor [28], processing plant lairage [30]; and unpasteurized apple juice, spinach and salami [31,32]. Sixty-five percent $(65 \%)$ of STEC O157 outbreaks were transmitted primarily through consumption of food (beef and produce); the rest through animal contact (10\%), person-to-person $(10 \%)$, waterborne $(4 \%)$, and other or unknown medium $(11 \%)$ [33]. According to different studies, cattle hides and beef carcass contaminations are common particularly during the slaughter process. E. coli $\mathrm{O} 157: \mathrm{H} 7$ prevalence was $20.3 \%$ on hides and $6.7 \%$ on carcasses [34]. The prevalence of E. coli $\mathrm{O} 157: \mathrm{H} 7$ on hides was $50.3 \%$ when cattle were loaded onto a transporter [30]. Natural transmission of $E$. coli $\mathrm{O} 157$ between cattle is thought to be largely by the fecal-oral route, although transmission may be indirect through an environmental reservoir [35].

Many publications on the prevalence of E. coli O157:H7 are available in the United States of America; however, an overall single quantitative estimate of this specific serotype in individual cattle, products, and the environment is lacking. We, thus, conducted a meta-analysis study of E. coli $\mathrm{O} 157: \mathrm{H} 7$ in the United States of America to determine (a) a pooled prevalence in cattle, hides, carcass, and environmental samples, and (b) summarize concentrations of the serotype in cattle feces, hides, and carcass.

\section{Methods}

Meta-analysis, a statistical analysis of a large collection of analyses results from individual studies for the purpose of integrating the findings [36], was the method adopted in this study. The PRISMA statement (Preferred Reporting Items for Systematic Reviews and Meta-Analysis) [37] and the Moose Statement (Proposal for Reporting Meta-analysis of Observational Studies in Epidemiology) [38] protocols were selected.

\section{Study area and population}

The study area was the United States of America. All of the cattle in the country constitute the study population. Relevant databases were searched to screen and select publications for the final meta-analysis. Cattle studied in these selected publications were sampled from all the four regions (Northeast, Midwest, West, and South), consisting of 17 states mentioned by name; and "U.S. States", "Across U.S. States", "Western U.S., "North U.S., "South U.S”, "Midwest", “West", "South", where the states were unnamed (Table 1). The division of the regions into Northeast, South, West, and Midwest was based on the U.S. Census Burea.

\section{Search strategy}

Search terms used were, (i) Prevalence study: "Prevalence of Escherichia coli O157:H7 in cattle in the United States of America"; (ii) Prevalence of environmental samples study: "Shiga toxin
Escherichia coli O157:H7 contamination in environment, slurry, fruits, vegetables, pasture, food, and feed in the United States of America"; (iii) Concentration study: "Colony forming units of Escherichia coli O157:H7in the United States of America". PubMed

(www.ncbi.nlm.nih.gov./entrez/query.fcgi), Science Direct (www. sciencedirect.com), Google Scholar (http://scholar.google.com) were the three free database sources used in the study.

\section{Inclusion and exclusion criteria}

First author conducted the search. Two authors (first and second) screened records using all set criteria and selected publications used in the analysis. Complete agreement was reached by consensus. Methodology was discussed among authors including other persons and suggestions were incorporated. Criteria used to select eligibility of searched publications are listed (Table 2).

\section{Data extraction}

For all the studies data were extracted based on author(s), year of study, title of article, diagnostic method, production system (beef, dairy), cases (positive results), sample size, type of sample, cfu per gram of sample, $\mathrm{cfu} / \mathrm{square} \mathrm{cm}$, state, and type of article.

\section{Regional difference}

Differences in prevalence for individual, herd, and environment categories were analyzed between regions.

\section{Data analysis}

The inverse variance heterogeneity model (IVhet model) was used in this study. A better performance of the inverse variance heterogeneity model embedded in MetaXL software compared to the fixed effect or random effect models is described [51]. Heterogeneity among studies was determined to see whether there were true differences underlying the results of the studies or the variation in findings was due to chance. We used $I^{2}$ statistic to assess heterogeneity. A better measure of consistency between studies using $I^{2}$ is described [52]. Doi plots [53], which plots effect size against sample size are used to analyze and display publication bias. The overall effect size estimated in this study was prevalence. Methods for the meta-analysis of prevalence and double arcsine transformation are described [54]. Individual prevalence is defined as the number of animals that are positive (shed E. coli $\mathrm{O} 157: \mathrm{H7}$ ) among animals tested; and herd prevalence is the number of positive herds among total herds tested. A positive herd (or farm) is a herd which has at least one animal shedding E. coli O157:H7. Similar epidemiological approach was used to calculate hide, carcass, and environmental samples' prevalences. In this study, supershedders are defined as animals with E. coli O157:H7 concentrations of at least $10^{3}$ colony forming units ( $\mathrm{cfu}$ ) per gram of feces. Sensitivity analysis was done to asses if the overall effect size changes when outlying small or large values are excluded. The absence of significant changes shows that the estimated overall effect size is robust. Meta-regression was conducted to investigate whether particular covariates explain the observed heterogeneity between studies. Year, sample size, and region were extracted from publications eligible for quantitative meta-analysis. Differences between regions were analyzed using Chi square statistic. Test of homogeneity together with post hoc analysis using pair wise comparison method was selected for further analysis. MetaXL software version 5.3 [55] was used for quantitative metaanalyses. R statistical computing software version 4.0.5 (R Core Team, 2020; R Studio Team, 2020) was used for meta-regression analysis and to calculate Chi square values. 
Table 1: Study area showing the regions, states, and cattle population.

\begin{tabular}{|c|c|c|c|c|}
\hline Region & State & $\begin{array}{l}\text { Cattle population }(1,000 \\
\text { head) [39] }\end{array}$ & $\begin{array}{l}\text { This study (\% of } \\
\text { whole) }\end{array}$ & $\begin{array}{l}\text { Regions and/or States } \\
\text { (known/unknown) }\end{array}$ \\
\hline Northeast & New York & $1,420.0$ & 1.52 & (Known) \\
\hline \multirow[t]{6}{*}{ South } & Alabama & $1,290.0$ & 1.38 & \\
\hline & Louisiana & 775.0 & 0.83 & \\
\hline & North Carolina & 800.0 & 0.85 & \\
\hline & Oklahoma & $5,300.0$ & 5.66 & \\
\hline & Tennessee & $1,790.0$ & 1.91 & \\
\hline & Texas & $13,100.0$ & 14.00 & \\
\hline \multirow[t]{5}{*}{ Midwest } & Kansas & $6,500.0$ & 6.94 & \\
\hline & Nebraska & $6,850.0$ & 7.32 & \\
\hline & North Dakota & $1,950.0$ & 2.08 & \\
\hline & Ohio & $1,260.0$ & 1.35 & \\
\hline & Wisconsin & $3,450.0$ & 3.69 & \\
\hline \multirow[t]{6}{*}{ West } & California & $5,150.0$ & 5.50 & \\
\hline & Colorado & $2,650.0$ & 2.83 & \\
\hline & Idaho & $2,500.0$ & 2.67 & \\
\hline & Oregon & $1,250.0$ & 1.34 & \\
\hline & Utah & 800.0 & 0.85 & \\
\hline & Washington & $1,140.0$ & 1.22 & \\
\hline Total & 17 & $56,025,668^{a}$ & 59.86 & \\
\hline $\mathrm{NA}[40]^{b}$ & U.S. States & NK & NK & $\begin{array}{l}\text { Regions and/or states } \\
\text { unknown }\end{array}$ \\
\hline NA [41] & U.S. States & NK & NK & \\
\hline NA [42] & U.S. States & NK & NK & \\
\hline NA [16,43-46] & NA & NK & NK & \\
\hline NA [47] & Across U.S. States & NK & NK & \\
\hline West, South ${ }^{c}[48]$ & $\begin{array}{l}\text { Alabama, California, Washington state, } \\
\text { North Carolina, Tennessee }\end{array}$ & $10,170.0$ & 18.15 & \\
\hline Western U.S. [49] & NA & NK & NK & \\
\hline $\begin{array}{l}\text { North U.S., } \\
\text { South U.S.' }[50]\end{array}$ & NA & NK & NK & \\
\hline $\begin{array}{l}\text { Midwest, West, South }{ }^{c} \\
\text { [30] }\end{array}$ & $\begin{array}{l}\text { Kansas, Nebraska, Oklahoma, Texas, Idaho, Utah, } \\
\text { Colorado, Washington State, Oregon, California }\end{array}$ & $45,240.0$ & 80.75 & \\
\hline
\end{tabular}

NA not available, NK cannot be determined because of incomplete content in the original publication.

${ }^{a}$ U.S. total cattle population is $93,594,500$ head [39].

${ }^{b}$ Numbers in parenthesis stands for reference

'Mixed data

\section{Results}

The number of publications selected for the final meta-analysis is illustrated (Figure 1). Out of a total of 1737 publications screened 53 were selected to be used for the final quantitative meta-analysis.

\section{Prevalence of $E$. coli $0157: \mathrm{H} 7$ in cattle and the environment}

The pooled prevalence of $E$. coli $\mathrm{O} 157: \mathrm{H} 7$ in feedlot cattle in the United States of America was 10.96\% (95\% CI: 4.2-18.8\%) (n=23,048) (Table 3) (Figure 2). In dairy cattle, the pooled prevalence was $1.5 \%$ (95\% CI: $0.11-3.5 \%)(\mathrm{n}=10,188)$. The pooled herd prevalence was $31.7 \%$ (95\% CI: $10.2-55.5 \%)(n=377)$ in combined beef and dairy cattle herds. The difference in prevalence between beef and dairy cattle was significant $(\mathrm{p}<0.05)$. Unweighted individual prevalence ranged from 0.71 to $27.8 \%$ in feedlot cattle, 0.3 to $5.5 \%$ in dairy cattle, and 7.1 to $100 \%$ in herds. The pooled prevalence decreased from $10.96 \%(\sim 11 \%)$ to $10 \%$ when four outliers were excluded by sensitivity analysis (Figure 3). Similarly, $I^{2}$ dropped from 99 to 89 . Further exclusion of any outliers didn't change the pooled prevalence from $10 \%$.Among environmental samples, the highest prevalence was observed in produce $(8.1 \% ; 95 \%$ CI: $0-29.6 \%)$ followed by watershed and sediment samples (4.6\%; $95 \%$ CI: $0-12.2 \%)$. Prevalence of water taken from drinking troughs was low (2.4\%; 95\% CI: 0.39-5.1\%). Unweighted prevalence of environmental samples ranged from 1 to $68 \%$.

\section{Hide and carcass contamination}

The pooled prevalences of hide and carcass contamination were $54.7 \%$ (95\% CI: 41.7-67.5\%) and $21.3 \%$ (95\% CI: 9.7-34.2\%), respectively. Hide and carcass contamination showed $400 \%$ and $100 \%$ percent increases, respectively, from individual feedlot prevalence.

\section{Concentration of $E$. coli O157:H7}

Only seven (7) out of 792 publications screened were selected for final analysis. Due to lack of appropriate statistical model as data were produced based on different scales of measurement, it was not possible 
Table 2: Inclusion and exclusion criteria.

\begin{tabular}{|c|c|c|}
\hline Type of study & Inclusion criteria & Exclusion criteria \\
\hline \multirow[t]{6}{*}{ General criteria: } & $\begin{array}{l}\text { Escherichia coli 0157: } \mathrm{H7} \text { or Shiga toxin-producing } \\
\text { Escherichia coli } 0157: \mathrm{H7} \text {. }\end{array}$ & Escherichia coli O157: $\mathrm{H}^{-}$and non-O157 STEC. \\
\hline & $\begin{array}{l}\text { Study methods are cultural and molecular which detect at } \\
\text { least one shiga toxin (stx } 1, s t \times 2 \text { ) and intimin (eae) gene. }\end{array}$ & $\begin{array}{l}\text { Serological diagnostic method. } \\
\text { Outbreak results. }\end{array}$ \\
\hline & Cattle, male, female; all age groups; feedlot, dairy, or mixed. & $\begin{array}{l}\text { Pathogen inoculation studies, intervention and } \\
\text { treatments (antimicrobial use, feeding high concentrate, } \\
\text { treatments with phenolic acids, monensin, essential oils, } \\
\text { microbials, and probiotics). }\end{array}$ \\
\hline & $\begin{array}{l}\text { Publication type: original articles, abstracts, theses, short } \\
\text { communication, proceeding. }\end{array}$ & Reviews, books, news. \\
\hline & Language: English. & \\
\hline & Time frame: from 1980-8/15/2020. & \\
\hline \multicolumn{3}{|l|}{ Specific criteria: } \\
\hline \multirow[t]{5}{*}{ Prevalence in cattle } & Observational studies. & Phage prevalence study results. \\
\hline & Denominator included. & \\
\hline & $\begin{array}{l}\text { Sample size: } \geq 30 \text { (individual prevalence); any sample size for } \\
\text { herd prevalence. }\end{array}$ & \\
\hline & Fecal samples taken directly from the rectum & Fecal pats, hide, and carcass samples. \\
\hline & units of hides and carcass samples from processing plants & \\
\hline \multirow[t]{2}{*}{$\begin{array}{l}\text { Prevalence in environmental } \\
\text { samples }\end{array}$} & $\begin{array}{l}\text { Pasture soil, water (watershed, water trough), feed, pen, } \\
\text { feedlot surface area. }\end{array}$ & Fecal pats collected from pens, fields. \\
\hline & Fresh produce. & Hide and carcass samples. \\
\hline \multirow[t]{5}{*}{ Concentration } & cfu per gram or log cfu per gram of feces. & cfu per ml of sample. \\
\hline & Fecal samples taken directly from the rectum. & Hide and carcass samples. \\
\hline & Environmental samples. & Fecal pats. \\
\hline & cfu per 100 sqcm of hides and carcass samples & \\
\hline & Samples from outbreaks included. & \\
\hline
\end{tabular}

to estimate a concentration weighted effect size. Hence, the records were summarized as presented in the original publications (Table 4). The concentrations on feces ( $\mathrm{cfu} / \mathrm{g})$, hides $(\mathrm{cfu} / 100$ square $\mathrm{cm}$ ), and carcass surfaces (cfu/100 square $\mathrm{cm}$ ) ranged from 900-300,000, $5-9,800$, and $1-189$, respectively. In all of the final records selected, at least one supershedder was found in a herd.

\section{Regional difference}

The pooled individual prevalences (beef and dairy combined) were $4.8 \%, 12.3 \%, 0.39 \%$, and $0.96 \%$ for South, Midwest, West, and Northeast, respectively. Significant difference was observed in individual, herd, and environment prevalence between the regions $\left(\chi^{2}=903.14, \mathrm{p}=0.0000 ; \chi^{2}=11.06, \mathrm{p}=0.0039 ; \chi^{2}=13.59, \mathrm{p}=0.0004\right.$, respectively). In the individual animal post hoc analysis, each region was different from the other entire region. In the herd and environment prevalence, the Northeast was significantly different from the rest; however, the South, Midwest, and West regions didn't show significant differences among them.

\section{Discussion}

The study was conducted to determine the magnitude of $E$. coli O157:H7 serotype in cattle, products, and the environment with a single collective quantitative estimate. Studies selected covered all the four regions and at least seventeen states out of the fifty. When only states identified by name are considered, sampled cattle represent $59.86 \%$ of the study population. We couldn't compute the exact figure as a good number of publications didn't name states; hence, the true representation is greater.

\section{Prevalence in cattle}

A high presence of E. coli O157:H7 in cattle was observed. One in ten beef cattle and one in three cattle herd harbored the pathogen in the study area. In some studies, all herds tested were positive. In agreement to the findings of this study, a meta-analysis study from North America reported that the prevalence of $\mathrm{O} 157$ was $10.68 \%$ in fed feedlot and $1.79 \%$ in adult dairy cattle [76]. The design of many publications searched in this study lacked randomization and convenient sampling was used in study animal selection; thus, our result can overestimate (or underestimate) the true population parameter. E. coli O157:H7 and other STEC are shed transiently in the feces. As prevalence is a snap-shot of detecting the presence of infection, the true population parameter can be underestimated.

Prevalence was significantly higher in beef than dairy cattle in this study. However, the findings of a good number of studies reviewed showed prevalence was higher in dairy than beef cattle. For STEC O157, a review of global testing of cattle feces showed prevalence 


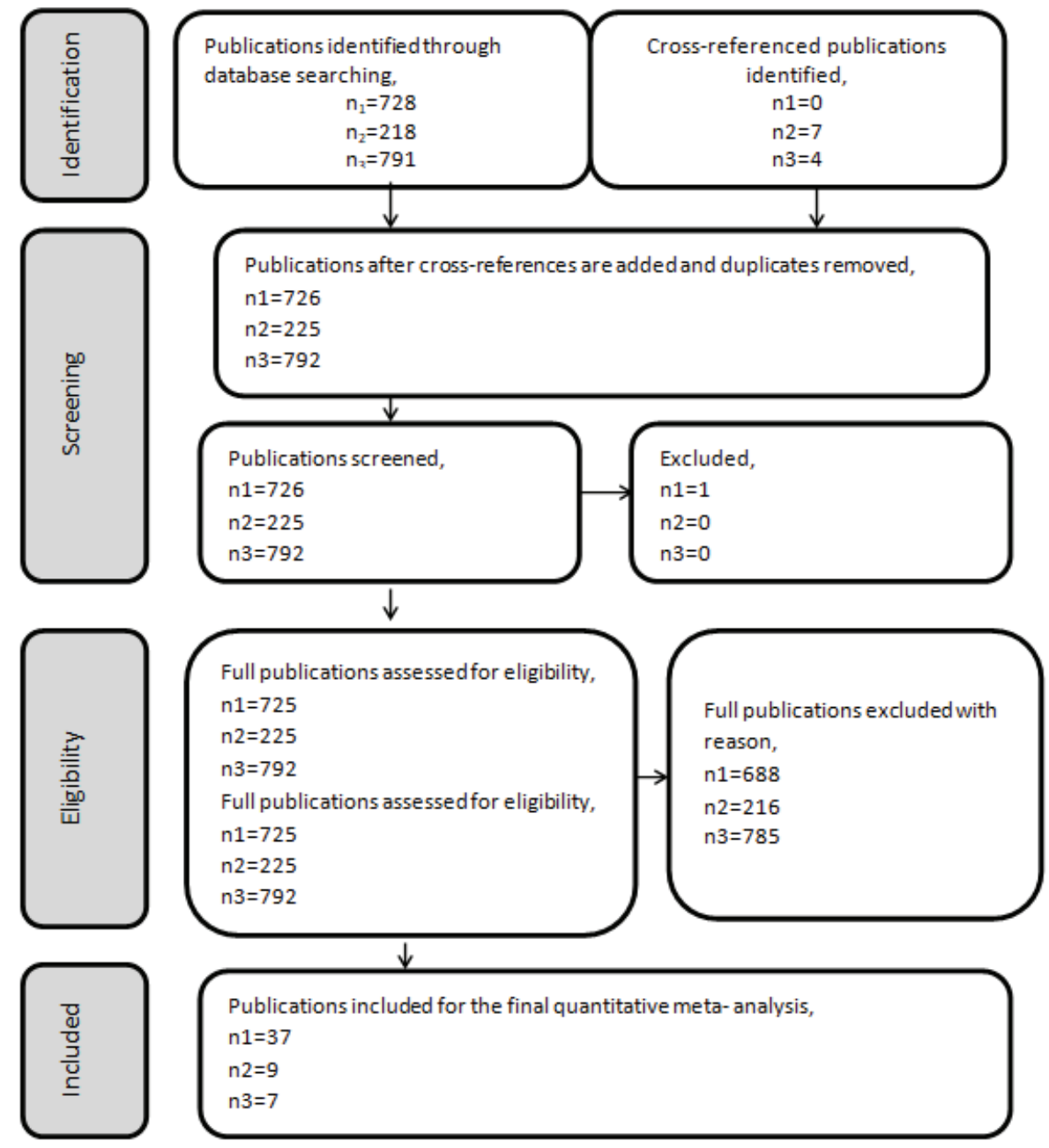

Figure 1: PRISMA flow diagram.

$n_{1}$ stands for prevalence of cattle, hide, and carcass contamination publications; $n_{2}$ prevalence of environmental sample publications; $n_{3}$ concentration publications).

ranges of $0.2-27.8 \%$ in beef cattle [77], and $0.2-48.8 \%$ in dairy cattle [78]. In Belgium, the highest prevalence of Escherichia coli $\mathrm{O} 157$ was found on dairy cattle farms $(61.2 \%)$, followed by mixed dairy and beef (44.4\%), beef (22.7\%), and veal calf farms (9.1\%) [79]. In Canada, an E. coli $\mathrm{O} 157: \mathrm{H} 7$ prevalence of $62.1 \%$ was reported in a dairy farm [78]. The prevalence was lower $(0.6 \%)$ in production systems of low animal density than when animals were kept under systems of high animal density (2.5\%) [77]. From these reports authors argue that increased prevalence of $E$. coli $\mathrm{O} 157: \mathrm{H} 7$ in feedlot cattle in the United States of America is related with management programs than animal type. Different management programs which include bedding and pen surfaces handling, manure management, biosecurity, cattle grouping, transportation and lairage, stress, feeding plan, and watering program is reviewed [8]. High deposition of organisms on pen floors, watering troughs, or open pasture facilitates infection particularly in overcrowded animals.

\section{Hide and carcass prevalence}

More than half of hide samples tested were found to be contaminated with E. coli O157:H7 in this study. The level of hide contamination was five times the prevalence, showing a connection between increased hide contamination and the hygiene of slaughter practices. Thus, safe disposal of gut contents and hygiene at slaughtering plants can reduce hide and carcass contamination.

\section{Environmental contamination}

Samples found contaminated were produce and different water sources (watering troughs, ponds, irrigation, and watersheds). Pathogen survivals in water troughs, pen floors, and in the immediate environment of animals are significant factors for infection. Water troughs and contaminated pen floors appeared to be particularly influential sources driving E. coli O157:H7 population dynamics [28,61]. Based on mathematical model assumptions, contaminated drinking water was the most important pathway of E. coli O157:H7 transmission to cattle [80]. Water is the major source of contamination for fresh produce [81]. Survival of culturable E. coli $\mathrm{O} 157$ for at least 245 days in microcosm sediments is reported [82]. The bacterium can remain alive in manure for 100 days [83]; or more than six months if the manure is kept under anaerobic condition at $16^{\circ} \mathrm{C}$ [84]. A few Restriction Endonuclease Digestion Patterns (REDPS) 
Table 3: Prevalence of Shiga toxin-producing Escherichia coli 0157:H7 in individual cattle and herds, environment, hide and carcass using IVhet model.

\begin{tabular}{|c|c|c|c|c|c|c|c|c|}
\hline $\begin{array}{c}\text { Prevalence } \\
\text { type }\end{array}$ & $\begin{array}{c}\text { Production } \\
\text { system }\end{array}$ & Sample & Positive & Sample size & Prevalencerange $^{a}$ & $\begin{array}{c}\text { Pooled } \\
\text { prevalence (\%) }\end{array}$ & $\begin{array}{c}95 \% \\
\text { Confidence } \\
\text { Interval }\end{array}$ & References \\
\hline \multirow[t]{2}{*}{$\begin{array}{l}\text { Individual } \\
\text { prevalence }\end{array}$} & Feedlot & Feces & 2,732 & 23,048 & $0.71-28.0$ & 10.96 & $4.2-18.8$ & {$[40,41,43-46,48,56-61,63]$} \\
\hline & Dairy & Feces & 211 & 10,188 & $0.3-5.5$ & 1.5 & $0.11-3.5$ & {$[29,42,48,59,62-67]$} \\
\hline $\begin{array}{l}\text { Herd } \\
\text { prevalence }\end{array}$ & Beef and dairy & Feces & 127 & 377 & 7.1-100 & 31.7 & $10.2-55.5$ & {$[29,40-42,44,57,60,63,66,67]$} \\
\hline $\begin{array}{l}\text { Hide } \\
\text { prevalence }\end{array}$ & $\begin{array}{l}\text { Beef and dairy } \\
\text { farms }\end{array}$ & Hide & 5864 & 10,700 & $11.0-71.0$ & 54.7 & 41.7-67.5 & {$[30,34,47,49,50,57,68,69]$} \\
\hline $\begin{array}{l}\text { Carcass } \\
\text { prevalence }\end{array}$ & $\begin{array}{l}\text { Beef and dairy } \\
\text { farms }\end{array}$ & carcass & 1497 & 6570 & $3.0-43.0$ & 21.3 & $9.7-34.2$ & {$[34,47,49,50,57,68,69]$} \\
\hline \multirow[t]{3}{*}{$\begin{array}{l}\text { Environment } \\
\text { prevalence }\end{array}$} & $\begin{array}{l}\text { Beef, dairy, and } \\
\text { ranches }\end{array}$ & $\begin{array}{l}\text { Water- } \\
\text { trough }\end{array}$ & 41 & 1631 & $1.7-5.3$ & 2.4 & $0.39-5.1$ & {$[29,64,67,70]$} \\
\hline & $\begin{array}{l}\text { Ponds, irrigation, } \\
\text { and public places }\end{array}$ & $\begin{array}{l}\text { watersheds } \\
\text { and water } \\
\text { sediment }\end{array}$ & 101 & 2038 & $4.0-68.2$ & 4.6 & $0-12.2$ & {$[70,71]$} \\
\hline & Vegetable farms & produce & 114 & 1402 & $7.9-25.0$ & 8.1 & $0-29.6$ & {$[72,73]$} \\
\hline
\end{tabular}

${ }^{a}$ Ranges of prevalences from indicated publications reported before pooling.

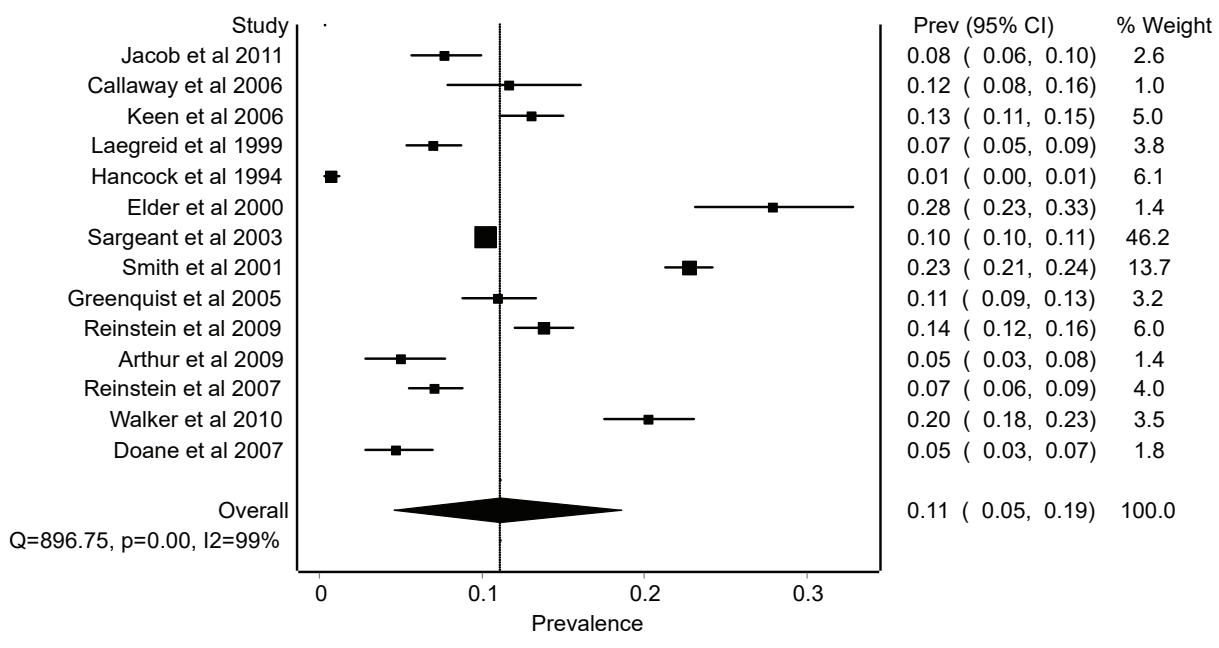

Figure 2: Forest plot of the prevalence in feedlot cattle.

persist and dominate over the entire feeding period in feedlot operation highlighting the importance of the farm environment, and not necessarily the incoming cattle, as a source of infection [85]. Water, hence, can be an easy but important environmental target for intervention against E. coli O157:H7 and other STEC transmission.

\section{Concentration}

The concentration of E. coli O157:H7 in feces taken directly from the terminal gut ranged from 900 to 300,000 organisms in one gram of feces. The amount is enough to contaminate other animals, hide, carcass, pen floors, and water troughs. At least $10^{4} \mathrm{cfu} / \mathrm{g}$ of EHEC in cattle feces are associated with contamination of hides, and subsequently, carcasses, and beef [74]. Less than 700 organisms were sufficient for E. coli O157:H7 to establish illness in humans [86]. Authors recommend that a pooled estimate generated using additional data is required to generate a representative concentration value for the country.

\section{Regional difference}

The Northeast region is different from the other three regions in all individual, herd, and environment prevalence. Climate, geographic location, or management differences are apparent between the Northeast and other regions. However, a rigorous study is needed to explain the observed difference.

We have learned three lessons from the study. In the estimation of the overall effect, an increased heterogeneity index $\left(I^{2}\right)$ was observed. Results of meta-regression showed region was found significant covariate accounting for $68.25 \%$ of heterogeneity $(p=0.0002)$. Year of study and sample size were not significant covariates $(p>0.05)$; however, year of study explained $9.77 \%$ of heterogeneity. One study with a large 


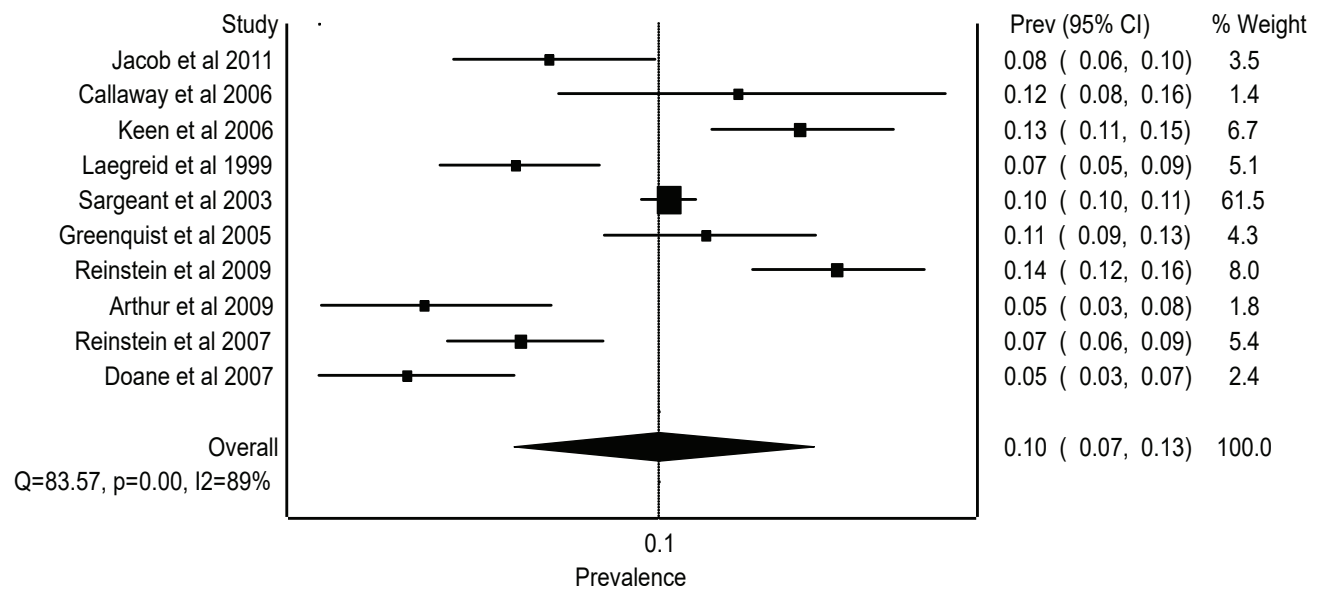

Figure 3: Forest plot of sensitivity analysis the prevalence in feedlot cattle after four outliers were excluded.

Table 4: Concentration of $E$. coli $\mathrm{O} 157: \mathrm{H7}$ in cattle feces, hide, carcass, and feedlot surface area.

\begin{tabular}{|c|c|c|c|c|}
\hline Sample type & Production system & Sample size ${ }^{a}$ & $\begin{array}{c}\text { Concentration } \\
\text { (cfu/g or cfu/100 } \mathrm{cm}^{2} \text { ) }\end{array}$ & References \\
\hline \multirow[t]{4}{*}{ Feces } & Beef & 122 & $1.6 \times 10^{3} \mathrm{cfu} / \mathrm{g}$ (median) & [69] \\
\hline & Dairy & 16 & $2.0 \times 10^{3}-1.0 \times 10^{5} \mathrm{cfu} / \mathrm{g}($ range $)$ & {$[42]$} \\
\hline & Feedlot & 200 & $9.0 \times 10^{2}-3.0 \times 10^{5} \mathrm{cfu} / \mathrm{g}$ (range) & [74] \\
\hline & Dairy & 1 & $7.9 \times 10^{3} \mathrm{cfu} / \mathrm{g}$ (maximum) & [49] \\
\hline \multirow[t]{4}{*}{ Hide } & Beef processing plant & 86 & $9 \cdot 8 \times 10^{3} \mathrm{cfu} / 100 \mathrm{~cm}^{2}$ (maximum) & [69] \\
\hline & & & $8.0 \times 10^{1} \mathrm{cfu} / 100 \mathrm{~cm}^{2}$ (median) & {$[69]$} \\
\hline & Beef processing plant & 245 & $4.0 \times 10^{1}-4.0 \times 10^{3} \mathrm{cfu} / 100 \mathrm{~cm}^{2}$ (range) & [47] \\
\hline & Dairy & 1 & $5.0 \times 10^{\circ} \mathrm{cfu} / 1,00 \mathrm{~cm}^{2}$ (maximum) & [49] \\
\hline \multirow[t]{3}{*}{ Carcass } & Beef processing plant & 40 & $4.6 \times 10^{1} \mathrm{cfu} / 100 \mathrm{~cm}^{2}$ (maximum) & {$[69]$} \\
\hline & & & $2.0 \times 10^{\circ} \mathrm{cfu} / 100 \mathrm{~cm}^{2}$ (median) & [69] \\
\hline & Beef processing plant & 40 & $1.0 \times 10^{0}-1.89 \times 10^{2} \mathrm{cfu} / 100 \mathrm{~cm}^{2}$ (range) & [47] \\
\hline Feedlot surface area & Feedlot & 40 & $3.6 \times 10^{5} \mathrm{cfu} / \mathrm{g}$ of soil (average) & [75] \\
\hline
\end{tabular}

${ }^{a}$ Enumerable sample sizes.

sample size was found influential. The major drawback of $I^{2}$ is its undue sensitivity to large sample sizes. Presence of heterogeneity indicates a difference among the studies pooled. It is advised that only similar studies are pooled and analyzed. The authors experienced a difficulty in finding a good number of publications satisfying assumption of homogeneity of results under set inclusion and exclusion criteria. Long time span of records published from 1980-2019, states, study design, and sample collection (swab and fecal grab), are the sources of heterogeneity. The increased heterogeneity of results observed in this study, in spite of rigorous selection criteria applied, calls for standardization of study designs in future investigation of STEC O157 serotypes. However, publication bias wasn't observed (Figure 4). The second lesson was that in the United States of America much attention is given to E. coli O157:H7 serotype. Recent reports increasingly show recognition of non-0157 STEC as a cause of EHEC human illnesses. ACDC report showed that $64 \%$ of all STEC infections in the United States are caused by non-O157 STEC [87]. Similarly, the total number of illnesses was higher in non-O157 STEC than E. coli O157:H7 [8891]. Consequently, the six non-O157 serotypes (O26, O103, O111,
O121, O145, and O45) are declared food adulterants [92]. In a study conducted in California, Cooley MB, et al. [70] reported a prevalence of $37.9 \%$ non-STEC in cattle, which is five-fold more than O157:H7 (7.1\%). The authors used three methods of culture modifications, O-typing ELISA (Enzyme Linked Immunosorbent Assay), Multilocus Variable Number Tandem Repeat Analysis (MLVA), and ompA gene sequencing in their investigations. Hence, the authors recommend extending study to non-O157 STEC epidemiology, shedding, and disease history. The last lesson learned was that most of the studies rarely used epidemiological study designs. To be valid and applicable to the general population, investigators must incorporate a component of randomization in their research methods.

The prevalence outputs obtained from this study are valid estimates closer to the population parameter on account of rigorous inclusion and exclusion criteria set, large sample size, effect model selected, and sensitivity analysis, not withstanding increased $I^{2}$. Hence, the outputs can be used for microbiological risk assessment, sample size calculation, economic analysis, and decision analysis for E. coli O157:H7. 


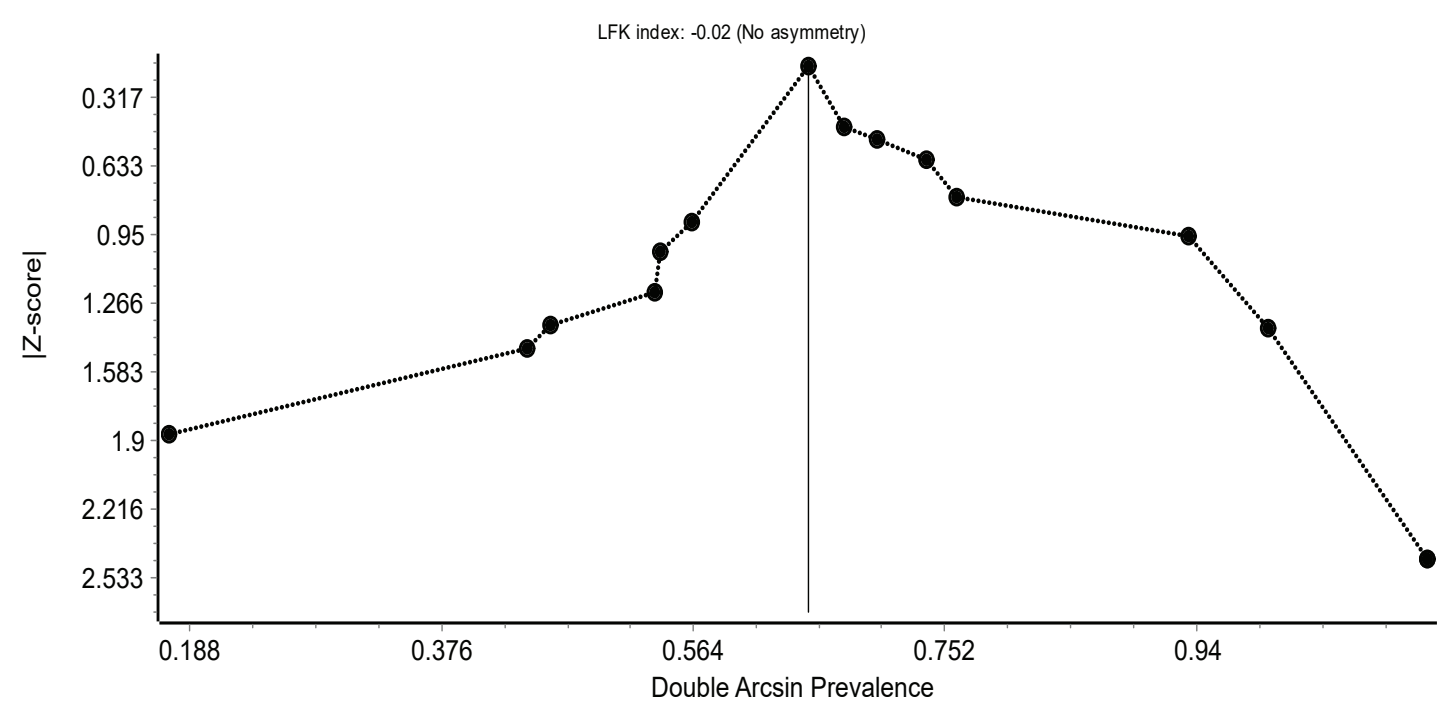

Figure 4: Doi plot displaying publication bias in the individual prevalence of feedlot cattle based on the IVhet model.

\section{Conclusion}

More than one out of ten beef and close to one-third of cattle herds shed E. coli O157:H7. In addition, at least one-fifth of carcass samples harbored the pathogen. The risk of contamination of animals, the environment, food, and humans in the United States of America due to E. coli $\mathrm{O} 157: \mathrm{H} 7$ is clearly evident. Pre-harvest control strategies (antimicrobials, vaccination, treatment with probiotics, administration of bacteriophages, and modification of the diet) are limited in reducing shedding. In both beef and dairy, on-farm management activities geared to achieve hygiene of pen surfaces, bedding, lairage, transportation, water trough, and feed handling are thus recommended for best outcome. Proper manure removal is critical. Avoidance of stress in beef cattle operations reduces colonization of the gut and thence eliminates or minimizes shedding to a minimum. To effectively protect the public from foodborne illnesses caused by Escherichia coli O157:H7, all control strategies should target cattle, the most important reservoir host.

\section{Conflict of Interest}

There is no conflict of interest.

\section{References}

1. Griffin PM, Tauxe RV (1991) The Epidemiology of infections caused by Escherichia coli 0157: $\mathrm{H7}$, other enterohemorrhagic E. coli, and the associated hemolytic uremic syndrome. Epidemiol Rev 13: 6098.

2. Gyles CL (2007) Shiga toxin-producing Escherichia coli: an overview. J Anim Sci 85: E45-E62.

3. Karmali MA, Gannon V, Sargeant JM (2010) Verocytotoxin-producing Escherichia coli (VTEC). Vet Microbiol 140: 360-370.

4. Ferens WA, Hovde CJ (2011) Escherichia coli O157:H7: animal reservoir and sources of human infection. Foodborne Pathog Dis 8 : 465-487.

5. Bach SJ, McAllister TA, Veira DM, Gannon VPJ, Holley RA (2002) Transmission and control of Escherichia coli O157:H7-A review. Can J Anim Sci 82: 475-490.
6. Sapers GM, Doyle MP (2014) Scope of the produce contamination problem. In: Matthews KR, Sapers GM, Gerba CP (eds) The produce contamination problem, $2^{\text {nd }}$ edition, Academic Press, Amsterdam, Netherlands.

7. Mead PS, Slutsker L, Dietz V, McCaig LF, Bresee JS, et al. (1999) Foodrelated illness and death in the United States. Emerg Infect Dis 5: 607-625.

8. Callaway TR, Edrington TS, Loneragan GH, Carr MA, Nisbet DJ (2013) Shiga toxin-producing Escherichia coli (STEC) ecology in cattle and management based options for reducing fecal shedding. Agric Food Anal Bacterio 13: 39-69.

9. Monaghan A, Byrne B, Fanning S, Sweeney T, McDowell D, et al. (2011) Serotypes and virulence profiles of non-0157 Shiga toxinproducing Escherichia coli isolates from bovine farms. Appl Environ Microbiol 77: 8662-8668.

10. Shridhar PB, Siepker C, Noll LW, Shi X, Nagaraja TG, et al. (2017) Shiga toxin subtypes of non-0157 Escherichia coli serogroups isolated from cattle feces. Front Cell Infect Microbiol 7: 121.

11. Dean-Nystrom EA, Bosworth BT, Cray WC Jr, Moon HW (1997) Pathogenicity of Escherichia coli O157:H7 in the intestines of neonatal calves. Infect Immun 65: 1842-1848.

12. Pruimboom-Brees IM, Morgan TW, Ackermann MR, Nystrom ED, Samuel JE, et al. (2000) Cattle lack vascular receptors for Escherichia coli 0157:H7 Shiga toxins. Proc Natl Acad Sci USA 97: 10325-10329.

13. Grauke LJ, Kudva IT, Yoon JW, Hunt CW, Williams CJ, et al. (2002) Gastrointestinal tract location of Escherichia coli $0157: \mathrm{H7}$ in ruminants. Appl Environ Microbiol 68: 2269-2277.

14. Lim JY, Li J, Sheng H, Besser TE, Potter K, et al. (2007) Escherichia coli $0157: \mathrm{H} 7$ colonization at the rectoanal junction of long duration culture positive cattle. Appl Environ Microbiol 73: 1380-1382.

15. Low CJ, McKendrick IJ, McKechnie C, Fenlon D, Naylor SW, et al. (2005) Rectal carriage of enterohemorrhagic Escherichia coli 0157 in slaughtered cattle. Appl Environ Microbiol 71: 93-97.

16. Walker C, Shi X, Sanderson M, Sargeant J, Nagaraja TG (2010) Prevalence of Escherichia coli 0157:H7 in gut contents of beef cattle at slaughter. Foodborne Pathog Dis 7: 249-255. 
17. Lloyd-Smith JO, Schreiber SJ, Kopp PE, Getz WM (2005) Superspreading and the effect of individual variation on disease emergence. Nature 438: 355-359.

18. Matthews L, Low JC, Gally DL, Pearce MC, Mellor DJ, et al. (2006) Heterogeneous shedding of Escherichia coli $\mathrm{O} 157$ in cattle and its implications for control. Proc Natl Acad Sci USA 103: 547-552.

19. Chase-Topping M, Gally D, Low C, Matthews L, Woolhouse M (2008) Supershedding and the link between human infection and livestock carriage of Escherichia coli 0157. Nat RevMicrobiol 6: 904-912.

20. Voetsch AC, Kennedy MH, Keene WE, Smith KE, Rabatsky-Her T, et al. (2007) Risk factors for sporadic Shiga toxin-producing Escherichia coli 0157 infections in FoodNet Sites 1999-2000. Epidemiol Infec 135: 993-1000.

21. Innocent GT, Mellor DJ, McEwen SA, Reilly WJ, Smallwood J, et al. (2005) Spatial and temporal epidemiology of sporadic human cases of Escherichia coli 0157 in Scotland 1996-1999. Epidemiol Infect 153: 1033-1041.

22. Michel P, Wilson JB, Martin SW, Clarke RC, McEwen SA, et al. (1999) Temporal and geographic distributions of reported cases of Escherichia coli 0157:H7 infection in Ontario. Epidemiol Infect 122: 193-200.

23. Valcour JE, Michel P, McEwen SA, Wilson JB (2002) Associations between indicators of livestock farming intensity and incidence of human shiga toxin-producing Escherichia coli infection. Emerg Infect Dis 8: 252-257.

24. Lahti E, Eklund M, Ruutu P, Siitonen A, Rantala AL, et al. (2002) Use of phenotyping and genotyping to verify transmission of Escherichia coli 0157:H7 from dairy farms. Eur J Clin Microbiol Infect Dis 21: 189-195.

25. Mora A, Blanco M, Blanco JE, Alonso MP, Dhabi G, et al. (2004) Phage types and genotypes of Shiga toxin-producing Escherichia coli 0157:H7 isolates from humans and animals in Spain: identification and characterization of two predominating phage types (PT2 and PT8). J Clin Microbiol 42: 4007-4015.

26. Barlow RS, Gobius KS, Desmarchelier PM (2006) Shiga toxinproducing Escherichia coli in ground beef and lamb cuts: results of a one-year study. Int J Food Microbiol 111: 1-5.

27. Rangel JM, Sparling PH, Crowe C, Griffin PM, Swerdlow DL (2005) Epidemiology of Escherichia coli O157:H7 outbreaks, United States, 1982-2002. Emerg Infect Dis 11: 603-609.

28. Ayscue P, Lanzas C, Ivanek R, Gröhn YT (2009) Modeling on-farm Escherichia coli 0157:H7 population dynamics. Foodborne Pathog Dis 6: 461-470.

29. Faith NG, Shere JA, Brosch R, Arnold KW, Ansay SE, et al. (1996) Prevalence and clonal nature of Escherichia coli $\mathrm{O} 157: \mathrm{H7}$ on dairy farms in Wisconsin. Appl Environ Microbiol 62: 1519-1525.

30. Arthur TM, Bosilevac JM, Brichta-Harhay DM, Guerini MN, Kalchayanand N, et al. (2007) Transportation and lairage environment effects on prevalence, numbers, and diversity of Escherichia coli 0157:H7 on hides and carcasses of beef cattle at processing. J Food Prot 70: 280-286.

31. Caprioli A, Morabito S, Brugère H, Oswald E (2005) Enterohaemorragic Escherichia coli: emerging issues on virulence and modes of transmission. Vet Res 36: 289-311.

32. Centers for Disease Control and Prevention (CDC) (2006) Ongoing multistate outbreak of Escherichia coli serotype 0157:H7 infections associated with consumption of fresh spinach-United States. Morb Mortal Wkly Rep 55: 1045-1046.
33. Heiman KE, Mody RK, Johnson SD, Griffin PM, Gould LH (2015) Escherichia coli 0157 outbreaks in the United States, 2003-2012. Emerg Infect Dis 21: 1293-1301.

34. Bosilevac JM, Wang R, Luedtke RBE, Hinkley S, Wheeler TL, et al. (2017) Characterization of enterohemorrhagic Escherichia coli on veal hides and carcasses. J Food Prot 80: 136-145.

35. Hancock DD, Besser TE, Rice DH, Ebel ED, Herriott DE, et al. (1998) Multiple sources of Escherichia coli $\mathrm{O} 157$ in feedlots and dairy farms in the northwestern USA. Prev Vet Med 35: 11-19.

36. Glass GV (1976) Primary, secondary, and meta-analysis of research. Educ Res 5: 3-8.

37. Moher D, Liberati A, Tetzlaff J, Altman DG (2009) Preferred reporting items for systematic reviews and meta-analyses: the PRISMA statement. PLoS Med 6: e1000097.

38. Stroup DF, Berlin JA, Morton SA, Olkin I, Williamson DG, et al. (2000) Meta-analysis of observational studies in epidemiology: a proposal for reporting. Meta-analysis Of Observational Studies in Epidemiology (MOOSE) group. JAMA 283: 2008-2012.

39. National Agricultural Statistics Service (NASS), Agricultural Statistics Board, United States Department of Agriculture (USDA) (2021) Cattle inventory by class-states and United States.

40. Laegreid WW, Elder RO, Keen JE (1999) Prevalence of Escherichia coli 0157:H7 in range beef calves at weaning. Epidemiol Infect 123: 291-298.

41. Sargeant JM, Sanderson MW, Smith RA, Griffin DD (2003) Escherichia coli 0157 in feedlot cattle feces and water in four major feedercattle states in the USA. Prev Vet Med 61: 127-135.

42. Zhao T, Doyle MP, Shere J, Garber L (1995) Prevalence of enterohemorrhagic Escherichia coli 0157:H7 in a survey of dairy herds. Appl Environ Microbiol 61: 1290-1293.

43. Arthur TM, Keen JE, Bosilevac JM, Brichta-Harhay DM, Kalchayanand $\mathrm{N}$, et al. (2009) Longitudinal study of Escherichia coli 0157:H7 in a beef cattle feedlot and role of high-level shedders in hide contamination. Appl Environ Microbiol 75: 6515-6523.

44. Greenquist MA, Drouillard JS, Sargeant JM, Depenbusch BE, Shi X, et al. (2005) Comparison of rectoanal mucosal swab cultures and fecal cultures for determining prevalence of Escherichia coli 0157:H7 in feedlot cattle. Appl Environ Microbiol 71: 6431-6433.

45. Reinstein S, Fox JT, Shi X, Alam MJ, Renter DG, et al. (2009) Prevalence of Escherichia coli 0157:H7 in organically and naturally raised beef cattle. Appl Environ Microbiol 75: 5421-5423.

46. Reinstein S, Fox JT, Shi X, Nagaraja TG (2007) Prevalence of Escherichia coli 0157: $\mathrm{H7}$ in gallbladders of beef cattle. Appl Environ Microbiol 73: 1002-1004.

47. Bosilevac JM, Arthur TM, Bono JL, Brichta-Harhay DM, Kalchayanand $\mathrm{N}$, et al. (2009) Prevalence and enumeration of Escherichia coli 0157:H7 and Salmonella in U.S. abattoirs that process fewer than 1,000 head of cattle per day. J Food Prot 72: 1272-1278.

48. Doane CA, Pangloli P, Richards HA, Mount JR, Golden DA, et al. (2007) Occurrence of Escherichia coli $0157: \mathrm{H7}$ in diverse farm environments. J Food Prot 70: 6-10.

49. Stromberg ZR, Lewis GL, Aly SS, Lehenbauer TW, Bosilevac JM, et al. (2016) Prevalence and level of enterohemorrhagic Escherichia coli in culled dairy cows at harvest. J Food Prot 79: 421-431. 
50. Rivera-Betancourt M, Shackelford SD, Arthur TM, Westmoreland $\mathrm{KE}$, Bellinger G, et al. (2004) Prevalence of Escherichia coli 0157:H7, Listeria monocytogenes, and Salmonella in two geographically distant commercial beef processing plants in the United States. J Food Prot 67: 295-302.

51. Doi SA, Barendregt JJ, Khan S, Thalib L, Williams GM (2015) Advances in the meta-analysis of heterogeneous clinical trials I: the inverse variance heterogeneity model. Contemp Clin Trials 45: 130-138.

52. Higgins JP, Thompsom SG, Deeks JJ, Altman DG (2003) Measuring inconsistency in meta-analysis. Br Med J 327: 557-560.

53. Furuya-Kanamori L, Barendregt JJ, Doi SAR (2018) A new improved graphical and quantitative method for detecting bias in metaanalysis. Int J Evid Based Healthc 16: 195-203.

54. Barendregt JJ, Doi SA, Lee YY, Norman R, Vos T (2013) Meta-analysis of prevalence. J Epidemiol Community Health 67: 974-978.

55. EpiGear International (2016) MetaXL software version 5.3. Sunrise Beach, Queensland, Australia.

56. Callaway TR, Edrington TS, Brabban AD, Keen JE, Anderson RC, et al. (2006) Fecal prevalence of Escherichia coli O157, Salmonella, Listeria, and Bacteriophage infecting E. coli $0157: \mathrm{H} 7$ in feedlot cattle in the southern plains region of the United States. Foodborne Pathog Dis 3:234-244.

57. Elder RO, Keen JE, Siragusa GR, Barkocy-Gallagher GA, Koohmaraie $M$, et al. (2000) Correlation of enterohemorrhagic Escherichia coli 0157 prevalence in feces, hides, and carcasses of beef cattle during processing. Proc Natl Acad Sci U S A 97: 2999-3003.

58. Jacob ME, Almes KM, Shi X, Sargeant JM, Nagaraja TG (2011) Escherichia coli 0157:H7 genetic diversity in bovine fecal samples. J Food Prot 74: 1186-1188.

59. Keen JE, Wittum TE, Dunn JR, Bono JL, Durso LM (2006) Shigatoxigenic Escherichia coli $\mathrm{O} 157$ in agricultural fair livestock, United States. Emerg Infect Diseases 12: 780-786.

60. Smith D, Blackford M, Younts S, Moxley R, Gray J, et al. (2001) Ecological relationships between the prevalence of cattle shedding Escherichia coli 0157:H7 and characteristics of the cattle or conditions of the feedlot pen. 2001. J Food Prot 64: 1899-1903.

61. Beauvais W, Gart EV, Bean M, Blanco A, Wilsey J, et al. (2018) The prevalence of Escherichia coli 0157:H7 fecal shedding in feedlot pens is affected by the water-to-cattle ratio: a randomized controlled trial. PLoS ONE 13: e0192149.

62. Dodson K, LeJeune J (2005) Escherichia coli O157:H7, Campylobacter jejuni, and Salmonella prevalence in cull dairy cows marketed in northeastern Ohio. J Food Prot 68:927-931.

63. Hancock DD, Besser TE, Kinsel ML, Tarr PI, Rice DH, et al.(1994) The prevalence of Escherichia coli 0157:H7 in dairy and beef cattle in Washington State. Epidemiol Infect 113: 199-207.

64. Jeong KC, Hiki O, Kang MY, Park D, Kaspar CW (2013) Prevalent and persistent Escherichia coli 0157:H7 strains on farms are selected by bovine passage. Vet Microbiol 162: 912-920.

65. McDonough PL, Rossiter CA, Rebhun RB, Stehman SM, Lein DH, et al. (2000) Prevalence of Escherichia coli 0157:H7 from cull dairy cows in New York state and comparison of culture methods used during preharvest food safety investigations. J Clin Microbiol 38: 318-322.

66. Murinda SE, Nguyen LT, Ivey SJ, Gillespie BE, Almeida RA, et al. (2002) Prevalence and molecular characterization of Escherichia coli 0157:H7 in bulk tank milk and fecal samples from cull cows: a 12-month survey of dairy farms in east Tennessee. J Food Prot 65: 752-759.
67. Plauche SB (2006) Detection and survival of Escherichia coli O157:H7 in cattle water troughs and the effects of cetylpyridinium chloride against Escherichia coli 0157:H7 biofilms on the surface of stainless steel. Doctoral Dissertation, Louisiana State University, Baton Rouge, USA.

68. Barkocy-Gallagher GA, Arthur TM, Rivera-Betancourt M, Nou X, Shackelford SD, et al. (2003) Seasonal prevalence of Shiga toxinproducing Escherichia coli, including 0157:H7 and non-0157 serotypes, and Salmonella in commercial beef processing plants. $J$ Food Prot 66: 1978-1986.

69. Brichta-Harhay DM, Arthur TM, Bosilevac JM, Guerini MN, Kalchayanand N, et al. (2007) Enumeration of Salmonella and Escherichia coli 0157: $\mathrm{H7}$ in ground beef, cattle carcass, hide and faecal samples using direct plating methods. J Appl Microbiol 103: $1657-1668$

70. Cooley MB, Jay-Russell M, Atwill ER, Carychao D, Nguyen K, et al. (2013) Development of a robust method for isolation of Shiga toxinpositive Escherichia coli (STEC) from fecal, plant, soil and water samples from a leafy greens production region in California. Plos one 8: e65716.

71. Cooley M, Carychao D, Crawford-Miksza L, Jay MT, Myers C, et al. (2007) Incidence and tracking of Escherichia coli 0157:H7 in a major produce production region in California. PloS one 2: e1159.

72. Cooley MB, Quiñones B, Oryang D, Mandrell RE, Gorski L (2014) Prevalence of Shiga toxin-producing Escherichia coli, Salmonella enterica, and Listeria monocytogenes at public access watershed sites in a California Central Coast agricultural region. Front Cell Infect Microbiol 4: 30.

73. Strawn LK, Fortes ED, Bihn EA, Nightingale KK, Gröhn YT, et al. (2012) Landscape and meteorological factors affecting prevalence of three food-borne pathogens in fruit and vegetable farms. Appl Environ Microbiol 79: 588-600.

74. Stromberg ZR, Lewis GL, Schneider LG, Erickson GE, Patel IR, et al. (2018) Culture-based quantification with molecular characterization of non-0157 and 0157 enterohemorrhagic Escherichia coli isolates from rectoanalmucosal swabs of feedlot cattle. Foodborne Pathog Dis 15: $26-32$

75. Berry ED, Wells JE (2012) Soil solarization reduces Escherichia coli 0157:H7 and total Escherichia coli on cattle feedlot pen surfaces. J Food Pro 75: 7-13.

76. Ekong PS, Sanderson MW, Cernicchiaro N (2015) Prevalence and concentration of Escherichia coli 0157 in different seasons and cattle types processed in North America: a systematic review and meta-analysis of published research. Prev Vet Med 121: 74-85.

77. Hussein HS, Bollinger LM (2005) Review: prevalence of Shiga toxinproducing Escherichia coli in beef cattle. J Food Prot 68: 2224-2241.

78. Hussein HS, Sakuma T (2005) Invited review: prevalence of Shiga toxin-producing Escherichia coli in dairy cattle and their products. J Dairy Sci 88: 450-465.

79. Cobbaut K, Berkvens D, Houf K, De Deken R, De Zutter L (2009) Escherichia coli 0157 prevalence in different cattle farm types and identification of potential risk factors. J Food Prot 72: 1848-1853.

80. Gautam R, Bani-Yaghoub M, Neill WH, Döpfer D, Kaspar C, et al. (2011) Modeling the effect of seasonal variation in ambient temperature on the transmission dynamics of a pathogen with a free-living stage: example of Escherichia coli 0157:H7 in a dairy herd. Prev Vet Med 102: 10-21.

Citation: Woube Y, Abdella E, Faraj R, Perry R, Reddy G, et al. (2021) Prevalence and Concentration of Escherichia coli O157:H7 in Cattle, Products, and the Environment in the United States of America: A Meta-Analysis Study. J Epidemiol Public Health Rev 6(3): dx.doi. 
81. Holvoet K, Sampers I, Seynnaeve M, Uyttendaele M (2014) Relationships among hygiene indicators and enteric pathogens in irrigation water, soil, and lettuce and the impact of climatic conditions on contamination in the lettuce primary production. Int J Food Micribiol 171: 21-31.

82. LeJeune JT, Besser TE, Hancock DD (2001) Cattle water troughs as reservoirs of Escherichia coli 0157. Appl Environ Microbiol 67: 3053 3057.

83. Kudva IT, Blanch K, Hovde CJ (1998) Analysis of Escherichia coli O157:H7 survival in ovine or bovine manure and manure slurry. Appl Environ Microbiol 64: 3166-3174.

84. Semenov $A V$, van Overbeek $L$, Termorshuizen $A J$, van Bruggen $A H$ (2011) Influence of aerobic and anaerobic conditions on survival of Escherichia coli 0157:H7 and Salmonella enteric serovar Typhimurium in Luriae-Bertani broth, farm-yard manure and slurry. J Environ Manage 92: 780-787.

85. LeJeune JT, Besser TE, Rice DH, Berg JL, Stilborn RP, et al. (2004) Longitudinal study of fecal shedding of Escherichia coli 0157:H7 in feedlot cattle: predominance and persistence of specific clonal types despite massive cattle population turnover. Appl Environ Microbiol 70: 377-384.

86. Tuttle J, Gomez T, Doyle MP, Wells JG, Zhao T, et al. (1999) Lessons from a large outbreak of Escherichia coli 0157:H7 infections: insights into the infectious dose and method of widespread contamination of hamburger patties. Epidemiol Infect 122: 185-192.
87. Scallan E, Hoekstra RM, Angulo FJ, Tauxe RV, Widdowson M, et al. (2011) Foodborne illness acquired in the United States: major pathogens. Emerg Infect Dis 17: 7-15.

88. Batz MB, Hoffmann S, Morris Jr, JG (2012) Ranking the disease burden of 14 pathogens in food sources in the United States using attribution data from outbreak investigations and expert elicitation. J Food Prot 75: 1278-1291.

89. Fey PD, Wickert RS, Rupp ME, Safranek TJ, Hinrichs SH (2000) Prevalence of non-0157:H7 shiga toxin-producing Escherichia coli in diarrheal stool samples from Nebraska. Emerg Infect Diseases 6 : 530-633.

90. Hoffman S, Batz MB, Morris Jr JG (2012) Annual cost of illness and quality-adjusted life year losses in the United States due to 14 foodborne pathogens. J Food Prot 75: 1292-1302.

91. Smith JL, Fratamico PM, Gunther NW 4 $4^{\text {th }}$ (2014) Shiga toxinproducing Escherichia coli. Adv Appl Microbiol 86: 145-197.

92. Food Safety and Inspection Service (FSIS), U.S. Department of Agriculture (2012) Shiga toxin-producing Escherichia coli in certain raw beef products. Federal Register 31975, Vol. 77, No. 105, 2012; 9 CFR Parts 416, 417, and 430, Docket No. FSIS-2010-0023. 